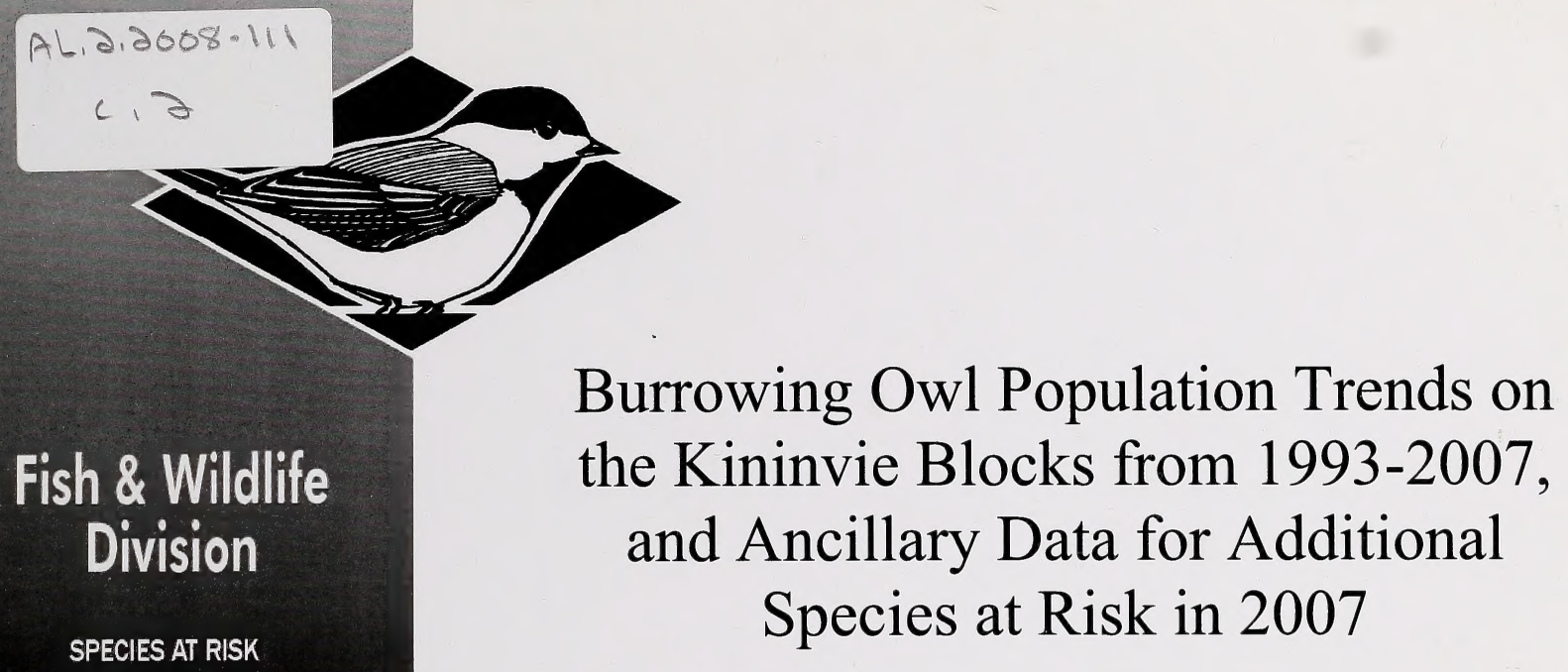

Burrowing Owl Population Trends on

Fish \& Wildlife Division

SPECIES AT RISK the Kininvie Blocks from 1993-2007, Species at Risk in 2007

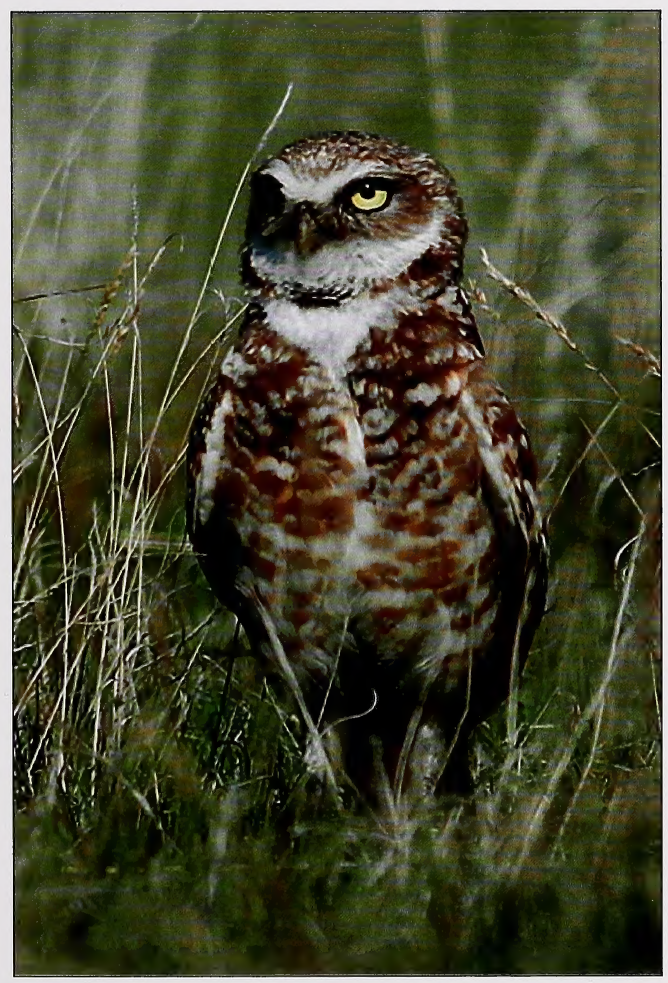

Alberta Species at Risk Report No. 116 
Digitized by the Internet Archive in 2016 


\title{
Burrowing Owl Population Trends on the Kininvie Blocks from 1993-2007, and Ancillary Data for Additional Species at Risk in 2007
}

Scott D. Stevens and Arlen W. Todd

\author{
Alberta Species at Risk Report No. 116 \\ February 2008
}

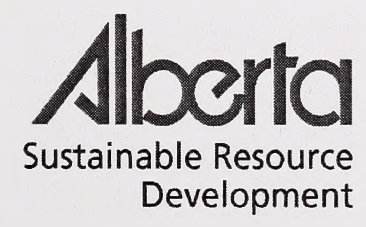


Publication No.:

ISBN: 978-0-7785-6555-5 (Printed Edition)

ISBN: 978-0-7785-6556-7 (On-line Edition)

ISSN: 1496-7219 (Printed Edition)

ISSN: 1496-7146 (On-line Edition)

Cover illustration: G.Court

For copies of this report, contact:

Information Centre - Publications

Alberta Environment / Alberta Sustainable Resource Development

Main Floor, Great West Life Building

9920108 Street

Edmonton, Alberta, Canada T5K 2M4

Telephone: (780) 422-2079

OR

Visit our web site at:

http://www.srd.gov.ab.ca/fishwildlife/speciesatrisk/default.aspx

A complete list of reports in this series can be viewed at:

http://www.srd.gov.ab.ca/fishwildlife/speciesatrisk/projectreports.aspx

This publication may be cited as:

Stevens, S.D., and A.W. Todd. 2008. Burrowing Owl Population Trends on the Kininvie Blocks from 1993-2007, and Ancillary Data for Additional Species at Risk in 2007. Alberta Sustainable Resource Development, Fish and Wildlife Division, Alberta Species at Risk Report No. 116, Edmonton, AB. 12 pp. 


\section{TABLE OF CONTENTS}

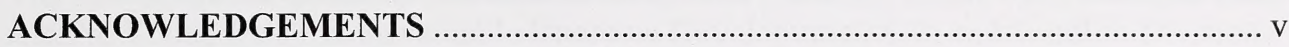

EXECUTIVE SUMMARY ....................................................................... vi

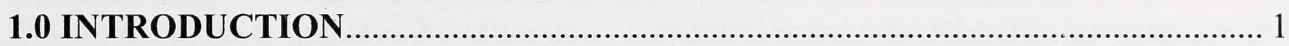

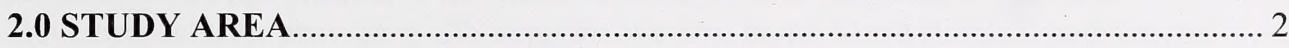

3.0 METHODS

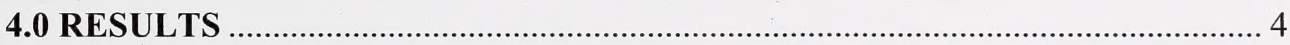

4.1. Burrowing Owls ....................................................................................... 4

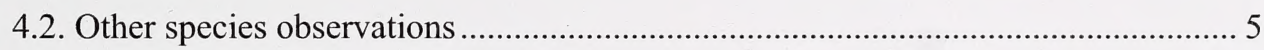

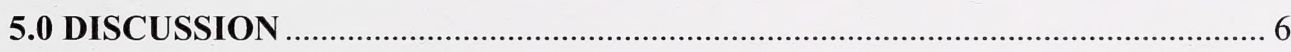

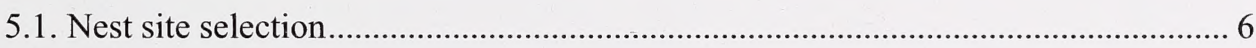

5.2. Burrowing owl population trends............................................................ 6

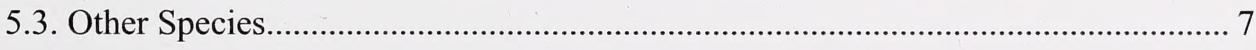

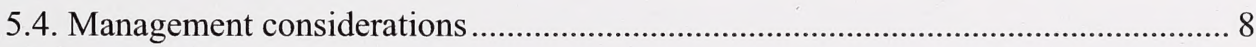

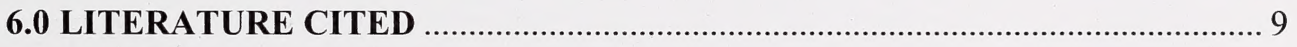

List of Titles in This Series ........................................................................ 13 


\section{LIST OF FIGURES AND TABLES}

Figure 1. Location of burrowing owl trend blocks (K-blocks) ….............................

Figure 2. Burrowing Owl nest density in the K-blocks ........................................

Table 1. At Risk, May be at Risk, and Sensitive species: observations at point count locations and blocks.......................................................... 


\section{ACKNOWLEDGEMENTS}

The 2007 trend block survey was conducted by Lisa Matthias, Cindy Platt, Scott Stevens, and Pat Young (Alberta Sustainable Resource Development, Fish and Wildlife Division). The authors express thanks to: the Eastern Irrigation District for allowing access to their lands; the survey participants; Troy Wellicome (Environment Canada) for loaning wildlife callers with burrowing owl calls; Reg Russell (Alberta Sustainable Resource Development, Fish and Wildlife Division), Cindy Platt and Lisa Matthias for manuscript reviews; Don Page (Resource Information Unit, Alberta Sustainable Resource Development), for providing GIS support. We also thank Steve Brechtel and Trevor Rhodes (Alberta Sustainable Resource Development, Fish and Wildlife Division) for encouraging the survey and contributing funding. 


\section{EXECUTIVE SUMMARY}

Declining populations of burrowing owls in both Canada and Alberta have led to status designations of Endangered, both nationally and provincially. Alberta's Burrowing Owl Recovery Team published a ministerial-approved provincial recovery plan in 2005 . The plan recommends continuing the provincial burrowing owl monitoring program in the 160 quarter sections of primarily native prairie in the Eastern Irrigation District, east and south of Brooks, collectively known as the Kininvie Blocks (herein, K-blocks).

Burrowing owl nest density has been indexed in the K-blocks 11 of the 15 years spanning 1993-2007, with the most recent surveys completed in 2007. Survey techniques remained consistent, to ensure a valid index of year-to-year trends. Declines in nest density have been recorded consistently since 1997. Observations in 2007 reconfirm and extend that declining trend; only two active burrowing owl nests were located, which equates to a decline of more than $86 \%$ in the last ten years, and a $60 \%$ decline since 2004 , the year of the most recent, preceding survey. This report documents burrowing owl nest density from 1993-2007, and includes descriptions of nest sites located in 2007.

Given the migratory nature of burrowing owls, factors which contribute to their decline may be occurring in the wintering areas and on migration routes outside of Alberta. Within the context of local populations in the K-blocks, and with diminishing sample sizes, it is difficult to assess factors contributing to the decline. Nonetheless, it is possible that cumulative effects from the oil and gas sector, and other human activities (such as increased vehicular traffic) could be playing a role in the decline by affecting adult survival or nesting success. Further, additions to the prairie landscape such as fences, utility poles, and artificial nests for hawks have enhanced habitat quality for those raptors and may be increasing predation on burrowing owls. To illustrate, the 2007 survey showed that other raptors, particularly northern harriers, are common on the K-blocks and four of seven artificial nest platforms contained active ferruginous hawk nests.

This report also includes observations of other bird species listed provincially as At Risk, May be At Risk, or Sensitive, recorded during this survey. Although status listings may have changed somewhat over the years, the species recorded are consistent with the standard protocol for the methods employed in the survey. This is the first time that such ancillary data have been reported from the survey on the trend blocks. Baird's sparrow and Sprague's pipit were both common and abundant on the survey; ferruginous hawks, northern harriers, Swainson's hawks, short-eared owls, loggerhead shrikes, long-billed curlews, and upland sandpipers were also observed. Ancillary data on these other species further illustrate the high value of periodic monitoring on the K-blocks. 


\subsection{INTRODUCTION}

The burrowing owl (Athene cunicularia) is a small owl, weighing 125-235 g, which lives up to nine years in the wild (Klimkiewicz 2002). The western sub-species (Athene cunicularia hypugea) that occurs in Alberta is migratory, spending the winter as far south as Texas and Central Mexico (Alberta Sustainable Resource Development and Alberta Conservation Association 2005; henceforth ASRD 2005). Burrowing owls arrive in Alberta between early April and mid-May and depart for the south beginning in late August (Haug et al. 1993). Pairs typically nest in burrows provided by Richardson's ground squirrels (Spermophilus richardsonii) or badgers (Taxidea taxus), but will occasionally use dens of coyote (Canis latrans) or fox (Vulpes spp.) (ASRD 2005). Females lay clutches averaging 9 eggs (Wellicome 2000) between late April and late May (Todd and Skilnick 2003). Young are capable of sustained flight at 40 days old and become independent in another 20 to 30 days (Todd 2001). In Alberta, nests are generally found on flat to undulating native pasture in the Mixedgrass and Dry Mixedgrass subregions of the Grassland Natural Region (Alberta Natural Heritage Information Centre 2004). Burrowing owls feed primarily on deer mice (Peromyscus maniculatus), meadow voles (microtus pennsylvanicus), sagebrush voles (Lemmiscus curtatus), grasshoppers, and other insects (Poulin 2003).

Over the past few decades, there have been widespread concerns about continuing declines of North American burrowing owl populations; the majority of jurisdictions within the burrowing owl's range give it special status (Haug et al. 1993, Holroyd et al. 2001, ASRD 2005). Although only $4 \%$ of the range of the western burrowing owl occurs in Canada, its breeding range has been reduced in Alberta and Saskatchewan, and it has been extirpated in British Columbia and Manitoba (ASRD 2005). In Alberta, the breeding range has decreased $44 \%$ in the last 30 years (ASRD 2005). Burrowing owls are classified as Endangered under Alberta's Wildlife Act. They are also nationally listed as Endangered (COSEWIC 2004).

Two areas in Alberta have been surveyed specifically for burrowing owls since the early 1990s as part of a provincial monitoring program. The Hanna trend blocks (herein, Hblocks) were established in 1991, and consist of 109 quarter sections $\left(70.6 \mathrm{~km}^{2}\right)$ of pasture and cultivated land in the general vicinity of the town of Hanna. Surveys carried out in the H-blocks during eight of the past 16 years showed a precipitous decline in the number of burrowing owls between 1991-1997, with numbers remaining very low in all subsequent years (Kissner and Skiftun 2004). The second monitoring area, the Kininvie blocks (K-blocks), was established in 1993, and encompasses 160 quarter sections (103.6 $\mathrm{km}^{2}$ ) located south and east of the town of Brooks. Including 2007, the K-blocks have been surveyed 11 of the past 15 years. Scobie (2002), Russell (2002), and Shyry (2004) all reported a continued decline in the number of burrowing owls occupying the Kblocks.

Here we report burrowing owl nest density observed in the K-blocks in 2007, compare that finding to previous surveys, and discuss possible reasons for burrowing owl population trends in the blocks. Although the survey protocol used in this study (Schmutz 
1994) is designed to monitor burrowing owl nest density within the blocks, we also report observations of other bird species listed provincially as At Risk, May be At Risk, or Sensitive, in order to begin to assess the importance of the K-blocks to other rare species of grassland birds.

\subsection{STUDY AREA}

The ten K-blocks, roughly staggered in a southerly direction, are located south and east of Brooks (Figure 1) on land owned by the Eastern Irrigation District (EID) within the County of Newell, in southeastern Alberta. Each is comprised of 16 adjacent quarter sections of dry mixed grass prairie. The habitat is primarily undulating native rangelands dominated by Stipa-Bouteloua-Agropyron vegetation communities (Strong 1992, Russell 2002). Ephemeral wetlands are abundant, with permanent wetlands also occurring. Oil and gas activities are common and widespread in the study area.

\subsection{METHODS}

All four observers were experienced in the visual and auditory identification of burrowing owls and other target species. The crew of four worked in two pairs; each pair was provided with maps for access to K-blocks, and geographic coordinates (UTM, NAD 83 ) for the center of each quarter section within the block. All terrain vehicles (ATVs) were used to access quarter section centers and handheld Garmin ${ }^{\circledR}$ GPS $76 \mathrm{Cx}$ or $12 \mathrm{XL}$ assisted navigation to center coordinates. Elevated points within $200 \mathrm{~m}$ of the quarter section centers were chosen for best visibility.

Based on terrain, observers would separate by roughly $200 \mathrm{~m}$ and conduct point count surveys. Each individual conducted a five minute passive scan, while making a $360^{\circ}$ pan of the quarter section using binoculars and listening to identify target species. We then broadcasted recorded breeding calls of an adult male burrowing owl (Foxpro ${ }^{\mathrm{TM}}$ digital wildlife caller) while scanning for an additional five minutes. The caller was placed above the cargo box on the ATV and the speaker rotated equally in each direction. Burrowing owl calls did not influence detection of other target species since a passive scan was first employed. Further, the call itself did not seem to affect the presence and detection of other species (see also Stevens and Wellicome 2005).

Surveys, which began at approximately 0600 and were completed by 1500 , were not conducted in rain or when wind speeds were greater than approximately $20 \mathrm{~km} / \mathrm{hr}$, B-4 on the Beaufort scale. Possible burrowing owl sightings, nests, and roosts were investigated before proceeding to the next quarter section. When adults, but not young, were observed, burrows were recorded as nests if nest material (usually dung), whitewash, prey remains or pellets were present in and around the burrow entrance. Adherence to this established burrowing owl protocol ensured that bias was minimized between observers and years (Russell 2002). Songbirds were identified by their territorial songs during the passive phase of the scan, and all other species by direct observation with binoculars. To avoid double-counting of individual birds, we discussed our observations at the end of each scan to ensure an accurate representation of the quarter section; one 
data sheet was shared between observers. Base data for maps was provided by the Spatial Data Warehouse ${ }^{\mathrm{TM}}$.

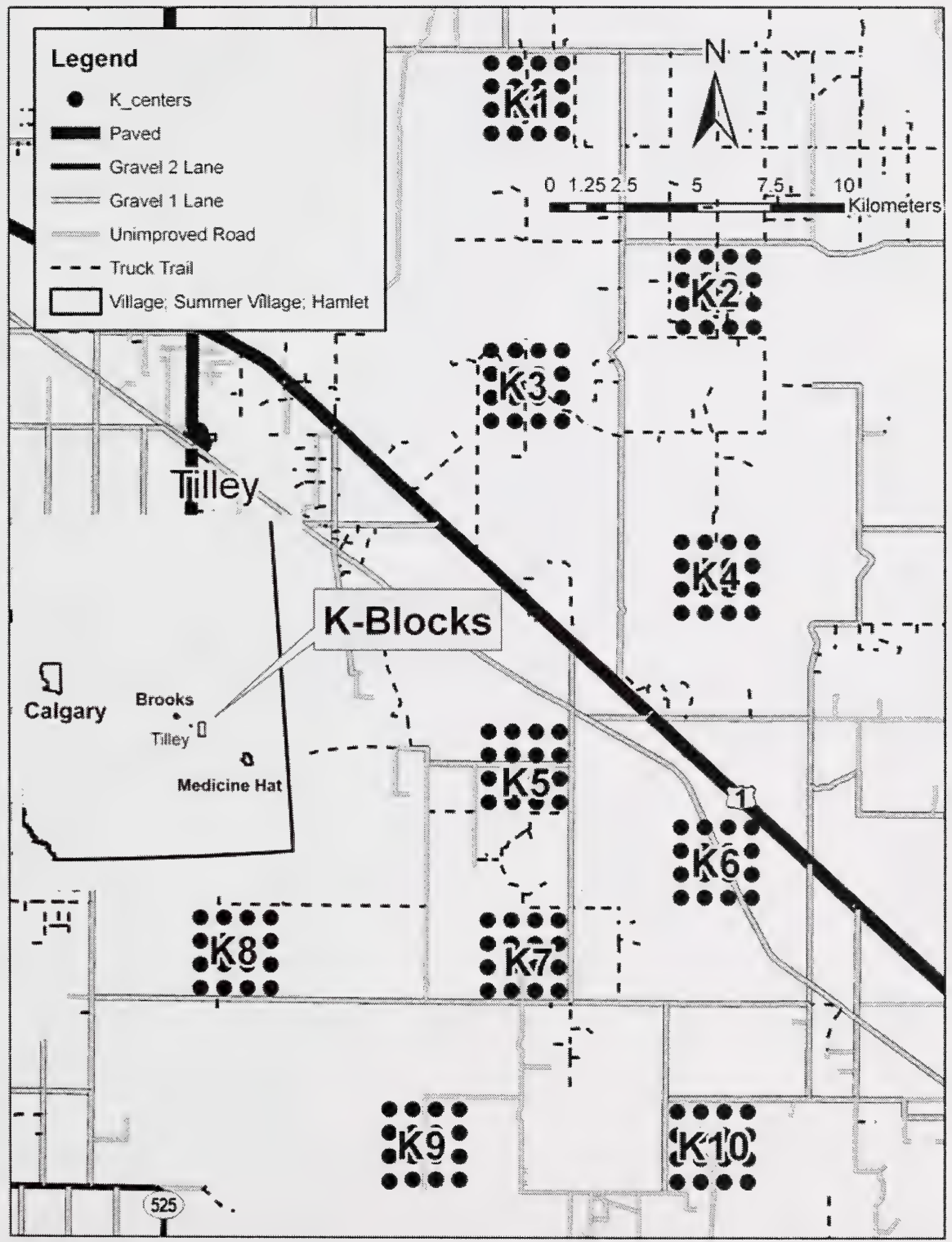

Figure 1. Location of burrowing owl trend blocks (K-blocks). 


\subsection{RESULTS}

\subsection{Burrowing Owls}

The 2007 K-block survey was conducted June 12-15. All 160 quarter sections were surveyed during that time. Two active burrowing owl nest sites were observed, one in K3 and one in K-4. Only one adult was observed at the K-3 nest, presumably the male, as it responded to the call broadcast. Numerous pellets and prey feathers occurred around the nest burrow entrance and tunnel, which were lined with vegetation. The burrow was located roughly $20 \mathrm{~m}$ from a well-head and $40 \mathrm{~m}$ from a gravel road to a well-site. Both adults were observed at the K-4 nest. Numerous pellets were present and the nest burrow entrance and tunnel were lined with cattle dung. The burrow was located roughly $300 \mathrm{~m}$ from modified pasture and approximately $2.1 \mathrm{~km}$ from the nearest road or trail.

Both nest sites were within $400 \mathrm{~m}$ of ephemeral wetlands, which were dry at the time of the survey. Further, both sites were situated close to active Richardson's ground squirrel (Spermophilus richardsonii) colonies, and in areas of high gas well density (41 and 43 gas wells per quarter section for K-3 and K-4, respectively). An additional burrowing owl site was observed in block K-5 where aged pellets, gray in appearance, were found at a burrow. However, there were no owls observed and we surmise the burrow was used in 2006, likely as a roost, but was unused in 2007.

Nest density in the K-blocks in 2007 was 1.93 nests $/ 100 \mathrm{~km}^{2}\left(2\right.$ nests $\left./ 103.6 \mathrm{~km}^{2}\right)$. That density corresponds to a $60 \%$ decrease since 2002 and 2004, and an $86 \%$ decrease since the maximum observed in 1997 (Figure 2).

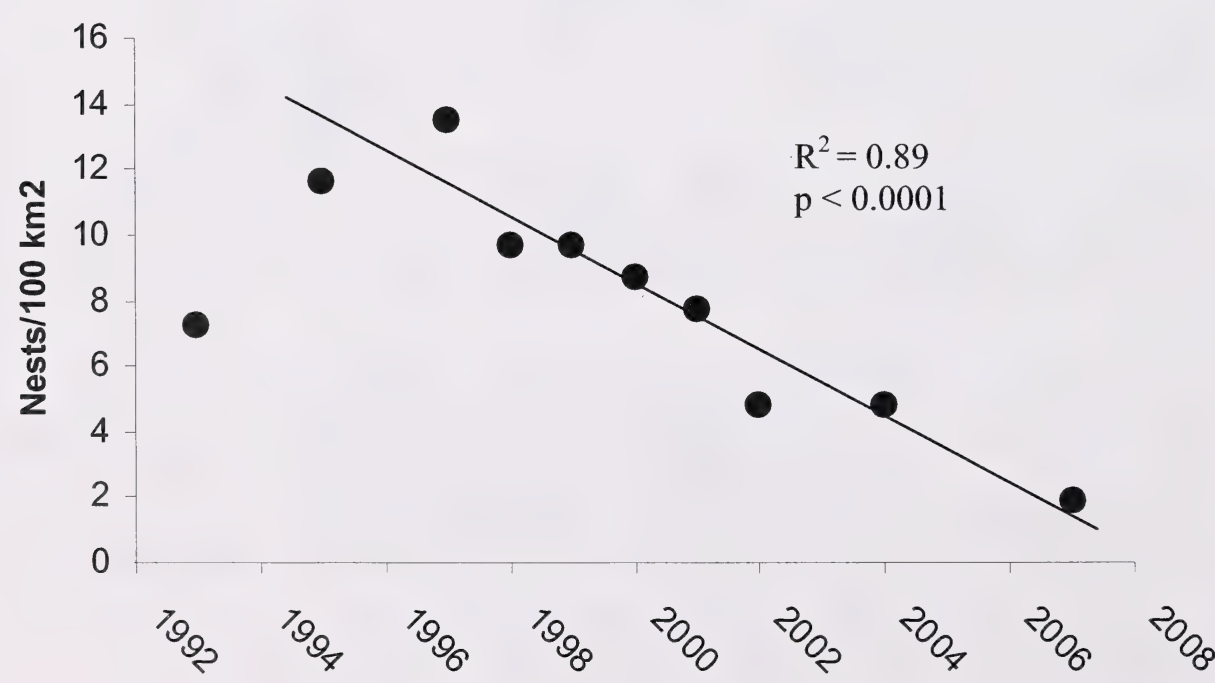

Figure 2. Burrowing owl nest density in the K-blocks from 1993-2007, showing a significant decline of $86 \%$ in the past 13 years $\left(R^{2}=0.89, n=9, p<0.0001\right.$. (Modified from Russell 2002, Shyry 2004, and ASRD 2005). 
There were 297 observations of bird species listed as At Risk, May be At Risk, or Sensitive (Table 1). Apart from burrowing owls, the only other At Risk species observed during the survey was the ferruginous hawk (Buteo regalis); other raptors included the short-eared owl (Asio flammeus; May be At Risk), and Swainson's hawk (Buteo swainsoni; Sensitive). The northern harrier (Circus cyaneus; Sensitive) was quite common, occurring in $16 \%$ of point counts and $80 \%$ of blocks surveyed. By far the most common species encountered was Baird's sparrow (Ammodramus bairdii; May be At Risk) and Sprague's pipit (Anthus Spragueii; Sensitive); both occurred in $100 \%$ of the blocks surveyed. Other notable species include the upland sandpiper (Bartramia longicauda; Sensitive) and loggerhead shrike (Lanius ludovicianus; Sensitive). Long-billed curlew (Numenius americanus; Sensitive) observations were rare and one American white pelican (Pelicanus erythrorhynchos; Sensitive) was observed en route to or from feeding grounds.

Table 1. At Risk, May be At Risk, and Sensitive species observations at point count locations and blocks, 2007, depicted as the number of, and percentage of, point counts on which the species was seen, and the percentage of blocks in which the species was observed.

\begin{tabular}{llccc}
\hline \multicolumn{1}{c}{ Species } & \multicolumn{1}{c}{ Status $^{1}$} & $\begin{array}{c}\text { \# Point } \\
\text { Count }\end{array}$ & $\begin{array}{c}\text { \% Point } \\
\text { Counts }\end{array}$ & \% Blocks \\
\hline Burrowing owl & At Risk & 2 & 1 & 20 \\
Ferruginous hawk & At Risk & 7 & 4 & 40 \\
Baird's sparrow & May be At Risk & 107 & 67 & 100 \\
Short-eared owl & May be At Risk & 4 & 3 & 30 \\
American white pelican & Sensitive & 1 & 1 & 10 \\
Loggerhead shrike & Sensitive & 2 & 1 & 10 \\
Long-billed curlew & Sensitive & 3 & 2 & 20 \\
Northern harrier & Sensitive & 25 & 16 & 80 \\
Sprague's pipit & Sensitive & 142 & 89 & 100 \\
Swainson's hawk & Sensitive & 3 & 2 & 30 \\
Upland sandpiper & Sensitive & 1 & 1 & 10 \\
\hline
\end{tabular}

\footnotetext{
${ }^{1}$ Indicates current general status ranking (ASRD 2007).
} 


\subsection{DISCUSSION}

\subsection{Nest site selection}

Burrowing owls tend to forage over areas of tall, dense vegetation such as low-lying emphemeral wetlands (Sissons 2003), likely as a function of higher vole and mice density in such areas (Pouling 2003). Both nest sites observed in our survey were situated near ephemeral wetlands, adding support to that hypothesis and further indicating the high conservation value of these basins. Several authors have reported that burrowing owls select pastures with higher density of ground squirrel burrows (James et al. 1991, Plumpton and Lutz 1993, Desmond and Savidge 1999) in highly grazed areas (Clayton and Schmutz 1999). Overall, grazing pressure appeared light in the K-blocks and ground squirrel colonies rare, both factors which could negatively influence the local settlement and persistence of burrowing owls. Long-term quantitative data are needed to accurately assess grazing regimes and ground squirrel distribution and abundance. Recent stable isotope analysis of feathers taken from burrowing owls nesting in Alberta suggests that $43 \%$ return to nest-sites in the same general area as they had occupied the previous summer (Duxbury 2004). That relatively low return rate illustrates the precarious position of the burrowing owl population in and around the K-blocks given the low number of owls that occupy the area.

\subsection{Burrowing owl population trends}

Data from the K-blocks over the past 13 years (1995-2007) show a highly significant decline of $86 \%$ in burrowing owl nest density (which equates to an average annual decline of $15 \%$ ). This is a higher rate of decline than that indicated by analysis from the North American Breeding Bird Survey for Alberta (11\% per year between 1996 and 2003; Sauer et al. 2004). In 1978, the population of burrowing owls in Alberta was estimated at more than 1500 pairs (Wellicome and Haug 1995). The most recent estimate is 200-400 pairs (ASRD 2005), which represents a 73-87\% decline in the provincial population since 1978 , a value remarkably similar to that documented for the K-blocks, which was over a shorter, more recent period. Further, a landholder index (questionnaire respondents) developed and maintained by Operation Grassland Community (Alberta Fish and Game Association) indicated a 90\% decline in burrowing owl numbers from 1991 to 2001, with numbers increasing slightly but remaining very low since 2002 (ASRD 2005). Likewise, intensive surveys in the Hanna area indicated very steep population declines during 1991-1997 (about 90\%), with numbers remaining at similar levels since then (ASRD 2005).

Factors which may be contributing to the decline in burrowing populations are many, and include, among others, habitat loss or change; fragmentation (Clayton 1997, Todd 2001); low first-year survival rates (Wellicome 2000); mortality on migration or wintering grounds (ASRD 2005); pesticide application (James and Fox 1987); increased rates of predation (Clayton and Schmutz 1999); and collisions with vehicles (Todd et al. 2003). Within the context of local population declines in the K-blocks, it is difficult to assess which of these are causative factors. Given that the K-blocks are still composed primarily 
of native prairie, it is unlikely that either habitat loss or pesticide application is particularly important in influencing local burrowing owl numbers. However, habitat change and cumulative effects from land uses, including oil and gas activities (e.g., increased vehicular traffic and sensory disturbance from drilling operations) could be playing a role in the decline by affecting adult survival or nesting success. While both nest sites in 2007 occurred in areas of high oil and gas activity, it is possible that only the burrowing owls most tolerant (i.e., habituated) to disturbance now remain. Further, additions to the prairie landscape such as fences, utility poles, and artificial nests for hawks have enhanced habitat quality for these other raptors, and may contribute to increased predation on burrowing owls. Indeed, our survey showed that large raptors are common on the K-blocks and seven artificial nest platforms for hawks were observed, four of which contained active ferruginous hawk nests.

\subsection{Other Species}

Baird's sparrow and Sprague's pipit, listed provincially as May be At Risk and Sensitive, respectively (ASRD 2007), were by far the most common species we encountered in the K-blocks. Both species prefer native grassland, rarely being found in cultivated fields or where native grasses have been replaced by introduced species (Dale et al. 1997, Robbins and Dale 1999). Although both species can be locally abundant, they have been declining rapidly in parts of their range, with the greatest decline occurring in Canada's prairieprovinces (Sauer et al. 2004). The abundance of Baird's sparrows and Sprague's pipits occurring in the K-blocks indicates that a relatively healthy grassland ecosystem is still in place.

Ferruginous hawks, listed provincially as Endangered under the Alberta Wildlife Act, occur in large tracts of open, generally arid habitats dominated by grasses or sagebrush (Bechard and Schmutz 1995). This species experienced a dramatic population decline between 1992 and 2000 (Stepnisky et al. 2002), and indications are that trend is continuing (Downy 2005). The presence of four active ferruginous hawk nests, although perhaps a negative influence on burrowing owls, indicates that the K-blocks are somewhat important to this rare species.

Long-billed curlews, listed provincially as Sensitive, were observed at only three point counts, despite recent population estimates for Alberta as high as 24,000 (Saunders 2001). The species has been declining in eastern parts of its range in Saskatchewan and has been extirpated in Manitoba (Saunders 2001). The curlew nests close to wetter areas in short-grass or mixed-grassland habitat (Hooper and Pitt 1996) and the K-blocks are situated in an area of high curlew density in the middle of the provincial range (see Hill 1998). Considering this, we expected long-billed curlews to be more common. It is possible that marbled godwits (Secure, ASRD 2007), which we found were very common on the blocks ( 41 observations in $90 \%$ of blocks), might be displacing long-billed curlews from the area. 
Short-eared owls, loggerhead shrikes, and upland sandpipers were other bird species observed in this survey. Without long-term data, inferences can not be made regarding trends of these other species in the K-blocks.

\subsection{Management considerations}

Aside from threats faced on their breeding grounds, it is possible that burrowing owl numbers both on a provincial scale and locally in the K-blocks are declining as a result of mortality factors and influences on habitat elsewhere in the continental range (e.g., migration and wintering areas in the U.S. and Mexico). Approaches to deal with those broader concerns are addressed in Canada's National Recovery Strategy (in preparation; Alberta Burrowing Owl Recovery Team 2005). However, it is clear that unless the current population trend is reversed, the burrowing owl is headed towards extirpation from Alberta and from Canada. In Alberta, we can affect survival and productivity of the owls that do return.

Alberta's burrowing owl recovery plan (Burrowing Owl Recovery Team 2005) calls for annual monitoring of the K-blocks. However, we recommend less frequent monitoring of these blocks (e.g., once every five years), considering that the near demise in the Kininvie blocks has now been well documented and reaffirmed. We recommend a continued reliance on the provincial index provided by Operation Grassland Community, supplemented by more local counts on properties held by stewardship cooperators (e.g. MULTISAR), and possibly new inventory initiatives where burrowing owls are presently more common, such as the Cessford-Pollockville and Pakowki Lake areas.

Burrowing owls are species of concern in environmental impact assessments for pipelines and other industrial activities in the province. Pipeline routes and drilling activities are planned so as to avoid burrowing owl nests, and restricted activity dates and setback distance guidelines have been put forward by Alberta Sustainable Resource Development (ASRD 2001), and are in the process of being revised. Another approach that could assist burrowing owl recovery is the implementation and maintenance of heterogeneity in grazing regimes (ASRD 2005). Further, installation of artificial burrows in Saskatchewan has been shown to reduce badger predation (Wellicome et al. 1997) and could be used in Alberta to that purpose. Finally, Operation Burrowing Owl, a nongovernment organization in Saskatchewan, has placed "burrowing owl crossing" signs within $1 \mathrm{~km}$ of nests located along roads, to reduce vehicular mortalities of owls.

The 297 observations of At Risk, May be At Risk, and Sensitive species in the K-blocks shows the importance of the area to native-grassland species. Future surveys of the Kblocks should continue to include these species, and results should be reported. Those data could be highly beneficial with respect to long-term population trend monitoring of these additional species. The methods employed in the K-block surveys since 1993 collected the same information as we did in this year's survey. Accordingly, an effort should be made to assemble that data and, where there is sufficient information, report trends in populations of these other species. 


\subsection{LITERATURE CITED}

Alberta Burrowing Owl Recovery Team. 2005. Recovery Plan for burrowing owl in Alberta. Alberta Sustainable Resource Development, Fish and Wildlife Division, Alberta Recovery Plan No. 6, Edmonton, AB. 24 pp.

Alberta Natural Heritage Information Centre (ANHIC). 2004. Natural regions and subregions of Alberta.URL: http://www.cd.gov.ab.ca/preserving/parks/anhic/themes.asp [Last updated: 22 September 2004].

Alberta Sustainable Resource Development. 2001. Protection of selected wildlife speciesand habitats with grassland and parkland natural regions of Alberta. URL: http://www.srd.gov.ab.ca/fishwildlife/guidelinesresearch/pdf/landuse/GrasslandParkland. pdf [Last updated 26 July 2001].

Alberta Sustainable Resource Development. 2007. The general status of Alberta Wildlife Species 2005. URL: http://www.srd.gov.ab.ca/fishwildlife/wildspecies/ [Last updated: 16 October 2007].

Alberta Sustainable Resource Development and Alberta Conservation Association. 2005. Status of the burrowing owl (Athene cunicularia) in Alberta: update 2005. Alberta Sustainable Resource Development, Wildlife Status Report No. 11 (Update 2005), Edmonton, AB. 28 pp.

Bechard, M.J., and J.K. Schmutz. 1995. Ferruginous Hawk (Buteo regalis). The Birds of North America, No.172 (A. Poole and F. Gill, eds.). The Academy of Natural Sciences, Philadelphia, PA, and The American Ornithologists' Union, Washington, DC. 18 pp.

Clayton, K.M. and J.K. Schmutz. 1999. Post-fledging ecology of burrowing owls in Alberta and Saskatchewan: dispersal, survival, habitat use, and diet. M.Sc. thesis. University of Saskatchewan, Saskatoon, SK. 66 pp.

COSEWIC. 2004. Committee on the status of endangered wildlife in Canada. URL: http://www.cosewic.gc.ca [Last updated: 21 June 2004].

Dale, B.C., P.A. Martin, and P.S. Taylor. 1997. Effects of hay management regimes on grassland songbirds in Saskatchewan. Wildlife Society Bulletin 25:616-626.

Desmond, M.J., and J.A. Savidge. 1999. Satellite burrow use by burrowing owl chicks and its influence on nest fate. Studies in Avian Biology 19:128-130.

Downy, B.L. 2005. The 2005 ferruginous hawk inventory and analysis. Alberta Sustainable Resource Development, Alberta Species at Risk Report No. 101. Edmonton, AB. 15pp. 
Duxbury, J.M. 2004. Stable isotope analysis and the investigation of the migrations and dispersal of peregrine falcons (Falco perigrinus) and burrowing owls (Athene cunicularia hypugaea). Ph.D. Thesis, University of Alberta, Edmonton, AB. 194 pp.

Harris, W.C., and S.M. Lamont. 1985. Saskatchewan burrowing owls: breeding distribution and habitat utilization. Unpublished report for Saskatchewan Natural History Society and Saskatchewan Parks and Renewable Resources, Regina, SK. 79 pp.

Haug, E.A., B.A. Millsap, and M.S. Martell. 1993. Burrowing owl (Speotyto cunicularia). The Birds of North America, No. 61 (A. Poole and F. Gill, eds.). The Academy of Natural Sciences, Philadelphia, PA, and The American Ornithologists' Union, Washington, DC. 20 pp.

Hill, D.P. 1998. Status of the long-billed curlew in Alberta. Alberta Environmental Protection, Fisheries and Wildlife Management Division, and Alberta Conservation Association, Wildlife Status Report No. 16, Edmonton, AB. 20 pp.

Holroyd, G.L., R. Rodriguez-Estrella, and S.R. Sheffield. 2001. Conservation of the burrowing owl in western North America: issues, challenges, and recommendations. Journal of Raptor Research 35:399-407.

Hooper, T.D. and M.D. Pitt. 1996. Breeding bird communities and habitat associations in the grasslands of the Chilcotin Region, British Columbia. Canada-British Columbia partnership agreement on forest resource development: FRDA II.

James, P.C. and G.A. Fox. 1987. Effects of some insecticides on productivity of burrowing owls. Blue Jay 45:65-71.

James, P.C., G.A. Fox and T.J. Ethier. 1990. Is the operational use of strychnine to control ground squirrels detrimental to burrowing owls? Journal of Raptor Research 24:120-123.

Kissner, K. and C. Skiftun. 2004. Habitat stewardship for species at risk in Special Areas 2, 3, and 4 of southeastern Alberta. Appendix I: burrowing owl trend block report (Hanna Blocks). Unpublished report for Alberta Sustainable Resource Development, Fish and Wildlife Division, Calgary, AB. 8 pp.

Klimkiewicz, M.K. 2002. Longevity records of North American birds. Version 2002.1. USGS Patuxent Wildlife Research Center. Bird Banding Laboratory. Laurel MD. URL: http//www.pwrc.usgs.gov/bbl/homepage/longvrec.htm.

Plumpton, D.L,. and R.S. Lutz. 1993. Nesting habitat use by burrowing owls in Colorado. Journal of Raptor Research 27:175-179.

Poulin, R.G. 2003. Relationships between burrowing owls (Athene cunicularia), small mammals, and agriculture. Ph.D. Thesis, University of Regina, Regina, SK. 145 pp. 
Robbins, M.B., and B.C. Dale. 1999. Sprague's Pipit (Anthus spragueii). The Birds of North America, No. 439 (A. Poole and F. Gill, eds.). The Academy of Natural Sciences, Philadelphia, PA, and The American Ornithologists' Union, Washington, DC. 20 pp.

Russell, R.F. 2002. 2002 burrowing owl trend block survey and monitoring, Brooks area. Alberta Sustainable Resource Development, Fish and Wildlife Division. Alberta Species at Risk Report No. 58, Edmonton, AB. 10 pp.

Sauer, J.R., J.E. Hines, and J. Fallon. 2004. The North American Breeding Bird Survey, results and analysis 1966-2003. Version 2004.1. USGS Patuxent Wildlife Research Center, Laurel, MD. URL: http://www.mbr-pwrc.usgs.gov/bbs/

Saunders, E.J. 2001. Population estimate and habitat associations of the long-billed curlew (Numenius americanus) in Alberta. Alberta Sustainable Resource Development, Fish and Wildlife Division. Alberta Species at Risk Report No. 25, Edmonton, AB. $57 \mathrm{pp}$.

Schmutz, J.K. 1993. Population trends of ferruginous hawks in Alberta, including a synthesis for prairie Canada. Unpublished report for the Committee on the Recovery of Nationally Endangered Wildlife in Canada (RENEW), Ottawa, ON. 21 pp.

Schmutz, J.K. 1994. A census of breeding burrowing owls in southern Alberta: 1994. Prepared for Alberta Environmental Protection, Natural Resources Service, Wildlife Management Division, Nongame Unit, Edmonton, AB. 15 pp.

Scobie, D. 2002. 2001 burrowing owl trend block survey and monitoring, Brooks and Hanna areas. Alberta Sustainable Resource Development, Fish and Wildlife Division, Alberta Species at Risk Report No. 51, Edmonton, AB. 13 pp.

Shyry, D.T. 2004. Burrowing owl population trend in Alberta: 2004 update for the Brooks (Kininvie) K-Blocks. Unpublished report prepared for Alberta Sustainable Resource Development, Fish and Wildlife Division, Calgary, AB. 6 pp.

Sissons, R.A. 2003. Food and habitat selection of male burrowing owls (Athene Cunicularia) on southern Alberta grasslands. M.Sc. Thesis, University of Alberta, Edmonton, AB. 92 pp.

Stepnisky, D.P., G.L. Erickson, J. Iwaasa, and B. Taylor. 2002. An evaluation of the ferruginous hawk population in Alberta based on recent trend data. Alberta Sustainable Resource Development, Fish and Wildlife Division. Alberta Species at Risk Report No. 52, Edmonton, AB. 16 pp.

Stevens, S.D. and T.I. Wellicome. 2005. A survey for federally listed grassland birds at First Nations Reserves. Canadian Field Naturalist 119:490-496.

Strong Ecological Land Survey Ltd. 1992. Ecoregions and ecodistricts of Alberta Volume 1. Alberta Forestry, Lands and Wildlife, Edmonton, AB. 77 pp. 
Todd, L.D. 2001. Survival and dispersal of juvenile burrowing owls (Athene cunicularia) during the post-fledging, pre-migratory period. M.Sc. Thesis, University of Regina, Regina, SK. 76 pp.

Todd, L.D. and J. Skilnick. 2003. Large clutch size of a burrowing owl, Athene cunicularia, found in Saskatchewan. Canadian Field Naturalist 116:307-308.

Todd, L.D., R.G. Poulin, T.I. Wellicome, and R.M. Brigham. 2003. Post-fledging survival of burrowing owls in Saskatchewan. Journal of Wildlife Management 67:512519.

Wellicome, T.I. 2000. Effects of food on reproduction in burrowing owls (Athene cunicularia) during three stages of the breeding season. Ph.D. Thesis, University of Alberta, Edmonton, AB. 113 pp.

Wellicome, T.I. and E.A. Haug. 1995. Second update of status report on the burrowing owl Speotyto cunicularia in Canada. Report prepared for the Committee on the Status of Endangered Wildlife in Canada, Canadian Wildlife Service, Ottawa, ON. 32 pp.

Wellicome, T.I. and G.L. Holroyd. 2001. The second international burrowing owl symposium: background and context. Journal of Raptor Research 35:269-273.

Wellicome, T.I., G.L. Holroyd, K. Scalise, and E.R. Wiltse. 1997. The effects of predator exclusion and food supplementation on burrowing owl (Speotyto cunicularia) population change. Pp. 487-497 in Duncan, J.R., D.H. Johnson, and T.H. Nicolls (eds.). Biology and conservation of owls of the northern hemisphere: proceedings of the second international symposium. U.S. Department of Agriculture Forest Service general technical report NC190. St. Paul, MN. 635 pp. 


\section{List of Titles in This Series}

(as of January 2008)

No. 1 Alberta species at risk program and projects 2000-2001, by Alberta Sustainable

Resource Development, Fish and Wildlife Division. (2001)

No. 2 Survey of the peregrine falcon (Falco peregrinus anatum) in Alberta, by R. Corrigan. (2001)

No. 3 Distribution and relative abundance of the shortjaw cisco (Coregonus zenithicus) in Alberta, by M. Steinhilber and L. Rhude. (2001)

No. 4 Survey of the bats of central and northwestern Alberta, by M.J. Vonhof and D. Hobson. (2001)

No. 52000 survey of the Trumpeter Swan (Cygnus buccinator) in Alberta, by M.L. James and A. James. (2001)

No. 6 2000/2001 Brassy Minnow inventory at Musreau Lake and outlet, by T. Ripley. (2001)

No. 7 Colonial nesting waterbird survey in the Northwest Boreal Region - 2000, by M. Hanneman and M. Heckbert. (2001)

No. 8 Burrowing owl trend block survey and monitoring - Brooks and Hanna areas, by D. Scobie and R. Russell. (2000)

No. 9 Survey of the Lake Sturgeon (Acipenser fulvescens) fishery on the South Saskatchewan River, Alberta (June-September, 2000), by L.A. Winkel. (2000)

No. 10 An evaluation of grizzly bear-human conflict in the Northwest Boreal Region of Alberta (1991 2000) and potential mitigation, by T. Augustyn. (2001)

No. 11 Harlequin duck monitoring in the Northern East Slopes of Alberta: 1998-2000 preliminary results, by J. Kneteman and A. Hubbs. (2000)

No. 12 Distribution of selected small mammals in Alberta, by L. Engley and M. Norton. (2001)

No. 13 Northern leopard frog reintroduction. Raven River - Year 2 (2000), by K. Kendell. (2001)

No. 14 Cumulative effects of watershed disturbances on fish communities in the Kakwa and Simonette watersheds. The Northern Watershed Project. Study 3 Progress report, by T. Thera and A. Wildeman. (2001)

No. 15 Harlequin duck research in Kananaskis Country in 2000, by C.M. Smith. (2001)

No. 16 Proposed monitoring plan for harlequin ducks in the Bow Region of Alberta, by C.M. Smith. (2001)

No. 17 Distribution and relative abundance of small mammals of the western plains of Alberta as determined from great horned owl pellets, by D. Schowalter. (2001)

No. 18 Western blue flag (Iris missouriensis) in Alberta: a census of naturally occurring populations for 2000 , by R. Ernst. (2000) 
No. 19 Assessing chick survival of sage grouse in Canada, by C.L. Aldridge. (2000)

No. 20 Harlequin duck surveys of the Oldman River Basin in 2000, by D. Paton. (2000)

No. 21 Proposed protocols for inventories of rare plants of the Grassland Natural Region, by C. Wallis. (2001)

No. 22 Utilization of airphoto interpretation to locate prairie rattlesnake (Crotalus viridis viridis) hibernacula in the South Saskatchewan River valley, by J. Nicholson and S. Rose. (2001)

No. 23 2000/2001 Progress report on caribou research in west central Alberta, by T. Szkorupa. (2001)

No. 24 Census of swift fox (Vulpes velox) in Canada and Northern Montana: 2000-2001, by A. Moehrenschlager and C. Moehrenschlager. (2001)

No. 25 Population estimate and habitat associations of the long-billed curlew in Alberta, by E.J. Saunders. (2001)

No. 26 Aerial reconnaissance for piping plover habitat in east-central Alberta, May 2001, by D.R.C. Prescott. (2001)

No. 27 The 2001 international piping plover census in Alberta, by D.R.C. Prescott. (2001)

No. 28 Prairie rattlesnake (Crotalus viridis viridis) monitoring in Alberta - preliminary investigations (2000), by S.L. Rose. (2001)

No. 29 A survey of short-horned lizard (Phrynosoma hernandesi hernandesi) populations in Alberta, by J. James. (2001)

No. 30 Red-sided garter snake (Thamnophis sirtalis parietalis) education and relocation project - final report, by L. Takats. (2002)

No. 31 Alberta furbearer harvest data analysis, by K.G. Poole and G. Mowat. (2001)

No. 32 Measuring wolverine distribution and abundance in Alberta, by G. Mowat. (2001)

No. 33 Woodland caribou (Rangifer tarandus caribou) habitat classification in northeastern Alberta using remote sensing, by G.A. Sanchez-Azofeifa and R. Bechtel. (2001)

No. 34 Peregrine falcon surveys and monitoring in the Parkland Region of Alberta, 2001, by R. Corrigan. (2002)

No. 35 Protocol for monitoring long-toed salamander (Ambystoma macrodactylum) populations in Alberta, by T. Pretzlaw, M. Huynh, L. Takats and L. Wilkinson. (2002)

No. 36 Long-toed salamander (Ambystoma macrodactylum) monitoring study in Alberta: summary report 1998-2001, by M. Huynh, L. Takats and L. Wilkinson. (2002)

No. 37 Mountain plover habitat and population surveys in Alberta, 2001, by C. Wershler and C. Wallis. (2002)

No. 38 A census and recommendations for management for western blue flag (Iris missouriensis) in Alberta, by R. Ernst. (2002)

No. 39 Columbian mountain amphibian surveys, 2001, by D. Paton. (2002) 
No. 40 Management and recovery strategies for the Lethbridge population of the prairie rattlesnake, by R. Ernst. (2002)

No. 41 Western (Aechmophorus occidentalis) and eared (Podiceps nigricollis) grebes of central Alberta: inventory, survey techniques and management concerns, by S. Hanus, H. Wollis and L. Wilkinson. (2002)

No. 42 Northern leopard frog reintroduction - year 3 (2001), by K. Kendell. (2002)

No. 43 Survey protocol for the northern leopard frog, by K. Kendell. (2002)

No. 44 Alberta inventory for the northern leopard frog (2000-2001), by K. Kendell. (2002)

No. 45 Fish species at risk in the Milk and St. Mary drainages, by RL\&L Environmental Services Ltd. (2002)

No. 46 Survey of the loggerhead shrike in the southern aspen parkland region, 2000-2001, by H. Kiliaan and D.R.C. Prescott. (2002)

No. 47 Survey of native grassland butterflies in the Peace parkland region of northwestern Alberta - 2001, by M. Hervieux. (2002)

No. 48 Caribou range recovery in Alberta: 2001/02 pilot year, by T. Szkorupa. (2002)

No. 49 Peace parkland native grassland stewardship program 2001/02, by A. Baker. (2002)

No. 50 Carnivores and corridors in the Crowsnest Pass, by C. Chetkiewicz. (2002)

No. 512001 Burrowing owl trend block survey and monitoring, Brooks and Hanna areas, by D. Scobie. (2002)

No. 52 An evaluation of the ferruginous hawk population in Alberta based on recent trend data, by D.P. Stepnisky, G.L. Erickson, J. Iwaasa and B. Taylor. (2002)

No. 53 Alberta amphibian call surveys. A pilot year. Final report, by L. Takats and C. Priestley. (2002)

No. 54 Utilization of a roadside survey technique to survey burrowing owl (Athene cunicularia hypugaea) in southeastern Alberta, by J. Nicholson and C. Skiftun. (2002)

No. 55 Alberta species at risk program and projects 2001-2002, by Alberta Sustainable Resource Development, Fish and Wildlife Division. (2002)

No. 56 Developing a habitat-based population viability model for greater sage-grouse in southeastern Alberta, by C.L. Aldridge. (2001)

No. 57 Peregrine falcon surveys and monitoring in the Northeast Boreal Region of Alberta, 2001, by R. Corrigan. (2002)

No. 582002 burrowing owl trend block survey and monitoring, Brooks area, by R.F. Russell. (2002)

No. 59 Rare plant inventory of the eastern edge of the lower foothills natural subregion, west-central Alberta, by J. Doubt. (2002)

No. 60 Western (Aechmophorus occidentalis) and eared (Podiceps nigricollis) grebes of central Alberta: 2002 field summary, by S. Hanus, L. Wilkinson and H. Wollis. (2002) 
No. 61 Inventory of western spiderwort (Tradescantia occidentalis) in Alberta: 2002, by S. Peters. (2003)

No. 62 Bullsnakes (Pituophis catenifer sayi) in Alberta: literature review and data compilation, by K.J. Kissner and J. Nicholson. (2003)

No. 63 Distribution of Ord's kangaroo rats in southeastern Alberta, by D.L. Gummer and S.E. Robertson. (2003)

No. 64 Lethbridge prairie rattlesnake conservation project: 2002/2003 progress report, by R.D. Ernst. (2003)

No. 65 Short-horned lizard (Phrynosoma hernandesi hernandesi) populations in Alberta - 2002 survey results, by J.D. James. (2003)

No. 66 Inventory and monitoring protocol for naturally occurring western blue flag (Iris missouriensis) in Alberta, by R.D. Ernst. (2003)

No. 67 The use of call playbacks for censusing loggerhead shrikes in southern Alberta, by D.R.C. Prescott. (2003)

No. 68 Survey of bats in northeastern Alberta, by A. Hubbs and T. Schowalter. (2003)

No. 69 Survey protocol for the Richardson's ground squirrel, by B.A. Downey. (2003)

No. 70 Population estimates and a survey protocol for ferruginous hawks in Alberta, by B.N. Taylor. (2003)

No. 71 Testing methods for detecting wolverine, by G. Mowat, C. Kyle and D. Paetkau. (2003)

No. 72 A multi-species conservation strategy for species at risk in the Milk River basin: year 1 progress report, by R.W. Quinlan, B.A. Downey, B.N. Taylor, P.F. Jones and T.B. Clayton. (2003)

No. 73 Long-toed salamander (Ambystoma macrodactylum) conservation in the Alberta foothills: 2002 field summary report, by L. Wilkinson and S. Hanus. (2003)

No. 74 Researching Amphibian Numbers in Alberta (RANA): 2002 provincial summary, by L. Wilkinson and S. Hanus. (2003)

No. 75 Distribution and habitat associations of the long-toed salamander (Ambystoma macrodactylum) in the Oldman River drainage, by K. Pearson. (2003)

No. 76 Prairie rattlesnake (Crotalus viridis) hibernacula: monitoring history in Alberta 1987-2002, by K.J. Kissner and J. Nicholson. (2003)

No. 77 Alberta species at risk program and projects 2002-2003, by Alberta Sustainable Resource Development, Fish and Wildlife Division. (2003)

No. 78 Northern leopard frog reintroduction: Year 4 (2002), by K. Kendell. (2003)

No. 79 Magrath Northern Leopard Frog Reintroduction Project - Year 1 Progress Report, by K.A. Romanchuck. (2003)

No. 80 Conservation Overview of Butterflies in the Southern Headwaters at Risk Project (SHARP) Area, by N. Kondla. (2004)

No. 81 Lethbridge Rattlesnake Conservation Project: 2003 Progress Report, by R. Ernst. (2004) 
No. 82 Shortjaw Cisco Species at Risk Assessment 2001, by M. Steinhilber. (2004)

No. 83 Researching Amphibian Numbers in Alberta (RANA): 2003 provincial summary, by L. Wilkinson and K. Kempin. (2004)

No. 84 Methods for Controlling Depredation on Piping Plovers in Alberta: A Literature Review and Synthesis, by R. Schmelzeisen, D.R.C. Prescott and L. Engley. (2004)

No. 85 Western Blue Flag Conservation Program: 3-Year Summary Report, by K.A. Romanchuk, R.D. Ernst, and R.W Quinlan (2004)

No. 86 MULTISAR: The Milk River Basin Habitat Suitability Models for Selected Wildlife Management Species, by B. A. Downey, B. L. Downey, R. W. Quinlan, O. Castelli, V. Remesz and P. F. Jones (eds.). (2004)

No. 87 MULTISAR: The Milk River Basin, A Multi-Species Conservation Strategy For Species at Risk: Year 2-Progress Report, by R.W. Quinlan, B. A. Downey, B. L. Downey, and P. F. Jones. (2004)

No. 88 Survey of Colonial Nesting Birds and Lakeshore Habitats in Northeast Alberta, by C. Found and A. Hubbs. (2004)

No. 89 The southern headwaters at risk project: A multi-species conservation strategy for the headwaters of the Oldman River. Volume 1: Introduction and natural processes, by F. Blouin. (2004)

No. 90 The southern headwaters at risk project: A multi-species conservation strategy for the headwaters of the Oldman River. Volume 2: Species Selection and Habitat Suitability Models, by F. Blouin, B.N.Taylor, and R.W.Quinlan (eds). (2004)

No. 91 Distribution, abundance and habitat selection of northern pygmy and barred owls along the eastern slopes of the Alberta Rocky Mountains, by M. D. Piorecky and D. R. C. Prescott. (2004)

No. 92 Survey of Aquatic Gastropods in the Central Parkland Subregion of Alberta, by D. R. C. Prescott, and M. M. Curteanu. (2004)

No. 93 The 2003 Loggerhead Shrike Survey in Alberta, by D. R. C. Prescott. (2004)

No. 94 Western (Aechmophorus occidentalis) and Eared (Podiceps nigricollis) Grebes of Central and Parkland Alberta: 2004 Field Summary, by G. Berg, L. Wilkinson, H. Wollis, and D. Prescott. (2004)

No. 95 Researching Amphibian Numbers in Alberta (RANA): 2004 provincial summary, by L. Wilkinson and G. Berg. (2004)

No. 96 Gillett's checkerspot in the southern headwaters at risk (SHARP) project area, by N.G. Kondla. (2005)

No. 97 Southern headwaters at risk project (SHARP) amphibian and western painted turtle (Chrysemys picta) surveys, 2003-2004, by K.J. Pearson. (2005)

No. 98 MULTISAR: A Multi-Species Conservation Strategy For Species at Risk: Year 3 Report, by B. L. Downey, B. A. Downey, R.W. Quinlan, and P. F. Jones. (2005)

No. 99 Implementation of the Alberta Piping Plover Recovery Plan, 2002-2004: Final Program Report, Alberta Piping Plover Recovery Team. (2005) 
No. 100 Alberta Species at Risk Program and Projects 2003-2004, by Alberta Sustainable Resource Development, Fish and Wildlife Division. (2005)

No. 101. The 2005 ferruginous hawk inventory and population analysis, by B. L. Downey. (2005)

No. 102 Western Spiderwort (Tradescantia occidentalis) Inventory in Alberta, 2005, by B.L. Remarchuk. (2006)

No. 103 Reproductive Biology of Female Prairie Rattlesnakes (Crotalus viridis viridis) in Alberta, by D. Jorgenson. (2007)

No. 104 Magrath Northern Leopard Frog Reintroduction Program: Final Report, by K. Romanchuk and R. Quinlan. (2005)

No. 105 The Southern Headwaters at Risk Project: A Multi-Species Conservation Strategy for the Headwaters of the Oldman River, Volume 3, Landscape Management - Selection and Recommendations, by F. Blouin. (2006)

No. 106 The Southern Headwaters at Risk Project: A Multi-Species Conservation Strategy for the Headwaters of the Oldman River Volume 4, BMP's and Land Use Guidelines for Focal Species, by F. Blouin. (2006)

No. 107 The Southern Headwaters at Risk Project: A Multi-Species Conservation Strategy for the Headwaters of the Oldman River, Volume 5, Landscape Pressures on Wide-ranging Species, by F. Blouin. (2006)

No. 108 MULTISAR: A Multi-Species Conservation Strategy for Species at Risk 2005-2006 Report, by B. A. Downey, B. L. Downey, R. W. Quinlan, and P.F. Jones. (2006)

No. 109 Western Rattlers and People: Conserving rattlesnakes in Lethbridge, by R.D. Ernst and R.W. Quinlan. (2006)

No. 110 Researching Amphibian Numbers in Alberta (RANA): 2005 Provincial Summary, by L. Wilkinson and G. Berg. (2006)

No. 111 Inventory of the Pinhorn Soapweed (Yucca glauca) and Yucca moth (Tegiticula yuccasella) population, 2004, by K. Foreman, J. Chandler, and L. Matthias. (2006)

No. 113 Monitoring Protocol for the Ord's Kangaroo Rat, by D. J. Bender, D. L. Gummer, and R. Dzenkiw. (2007)

No. 114 MULTISAR: A Multi-species Conservation Strategy for Species at Risk, 2006-2007 report, by Downey, B. A., R. W. Quinlan, P. F. Jones, and R. Elhert. (2007)

No. 115 Bird Populations on the Shoreline of Buffalo Lake: Identification of Priority Areas for Conservation, by Prescott, D.R.C. and S.D. Stevens (2007) 

. 